\title{
ЛІНГВОКОНЦЕПТОЛОГІЯ
}

УДК: 811.111: 81:42-13

М. О. Бєлова

\section{КУЛЬТУРНО МАРКОВАНА ЛЕКСИКА ЯК ЗАСІБ ОБ'ЄКТИВАЦІЇ КОНЦЕПТУ СТАТУС (на матеріалі британського художнього дискурсу)}

У роботі висвітлено особливості об'єктивації концепту СТАТУС за допомогою культурно маркованої лексики в британському художньому дискурсі. Зазначено, щзо в разі об'єктивації концепту в мові й мовленні він набуває статусу лексичного кониепту. Лексикалізація кониепту передбачає його об'єктивацію за допомогою тексичної системи мови, зокрема й культурно маркованої лексики (реалій, денотативно маркованої та конотативно маркованої фонової лексики), яка віддзеркалює культурну інформацію на різних рівнях структури концепту. У процесі дослідження виявлено типи культурно маркованої лексики, що залучаються для об'єктивації концепту СТАТУС у британському худонньому дискурсі, встановлено, які ознаки кониепту вони віддзеркалюють і яке місие в структурі концепту вони посідають.

Ключові слова: концепт, лексикалізація, реалія, денотативно маркований, конотативно маркований, дискурс.

Bielova M. Culturally-Marked Lexis as a Means of Objectivation of the Concept STATUS (Based on the Material of British Literary Discourse). The intent of the current research is to reveal how culturally-marked linguistic units lexicalize the concept STATUS in the present-day British literary discourse. The topicality of the research is proved by the scientific interest in the nature of lexical units in terms of their cultural significance as a means of presenting the concept STATUS (one of the key concepts in British worldview) in the present-day British literary discourse. The aim of the work is to elucidate the semantics of culturally-marked lexical units as a way of representing cultural specific information at different levels of the concept STATUS. The objective of the research is the verbalization of the concept STATUS by means of culturally-marked lexical units. The subject is the specificity of such verbalization the identification of which gives an opportunity to reveal culturally specific features of the studied concept. According to the aim of the paper the following tasks were set: to view the notion of culturally-specific lexis and provide its classification; to identify lexical concept and figure out the specificity of lexicalization as means of concept representation; to describe the structure of concept; to describe the concept STATUS as the object of the study; to single out the groups of lexical units that take 
part in the lexicalization of the concept STATUS and reveal its cultural specificity; to single out what feature these lexical units reveal and what place they occupy in the structure of the concept. The study revealed that culturally-marked lexical units that represent the concept STATUS in the present-day British literary discourse include oykonyms, social (educational) realia, realia that denote public organizations and institutions, social realia that name official hereditary titles; denotatively marked background vocabulary units which denotative meaning involves cultural information about the status of a person in the society; connotatively marked lexical units in the meaning of which culturally conditioned information is contained in the connotative component. As a result of the analysis it is revealed that realia reflect the features of the concept STATUS that are part of the descriptive zone of the encyclopedic field of the concept; denotatively marked background vocabulary units reflect the features that are part of the notional component of the studied concept; connotatively marked lexical units disclose features of the utilitarian zone of the interpretation field of the concept.

Key words: concept, lexicalization, realia, denotatively-marked, connotativelymarked, discourse.

\section{Вступ}

Вивчення взаємозв'язку мови та культури є одним з актуальних напрямів сучасної лінгвістики, зокрема й когнітивної. Це пояснюємо практичними потребами інтенсивної міжкультурної комунікації, що постійно зростають, а також недостатньою кількістю загальнотеоретичних досліджень. Наразі здійснено спробу дослідити культурний простір як основу формування концептів (Давиденко, 2019); знайшли подальшу розробку питання специфіки лінгвокультурного концепту (Домніч, 2017); виокремлено критерії ключових концептів культури (Саєвич, 2013); проаналізовано національну ідентичність та особливості британських лінгвокультурних концептів - PRIDE i NOBILITY (Сергієнко, 2015), ARROGANCE (Єфимчук, 2018), TRANSPORT (Чумакова, 2017) тощо. Незважаючи на значний інтерес до питань відображення культури в словниковому складі мови, методика дослідження культурно маркованих лексем, зокрема з огляду на їхню специфіку як засобу лексикалізації концептів, не розроблена. Це зумовлює актуальність цього дослідження, у якому пропонуємо алгоритм аналізу лексичних одиниць в аспекті їхньої культурологічної значущості як способу подання концепту СТАТУС у британському художньому дискурсі. 
Об’єктом дослідження є об’єктивація концепту СТАТУС за допомогою культурно маркованої лексики, предметом - специфіка об’єктивації культурної інформації в структурі концепту СТАТУС із залученням культурно маркованої лексики. Мета роботи - з'ясувати семантику культурно маркованих лексичних одиниць як способу об’єктивації культурної інформації на різних рівнях структури концепту СТАТУС. Мета роботи визначає iі завдання: 1) розглянути феномен культурно маркованої лексики й подати їі класифікацію; 2) надати визначення лексичного концепту й з'ясувати специфіку лексикалізації як способу подання концепту; 3) описати структуру лексичного концепту; 4) описати концепт СТАТУС як об’єкт дослідження; 5) з'ясувати групи культурно маркованої лексики, що беруть участь в об'єктивації концепту СТАТУС у британському художньому дискурсі; 6) визначити, які ознаки концепту СТАТУС об'єктивують культурно марковані лексичні одиниці та яке місце в структурі концепту вони посідають. Матеріалом дослідження слугували фрагменти британського художнього дискурсу, у якому функціонують культурно марковані лексичні одиниці на позначення концепту СТАТУС.

\section{Методи дослідження}

Мета роботи передбачає інтегративний підхід до розв'язання поставлених завдань, що передбачає використання таких методів і прийомів дослідження: дефінітивний метод, контекстний аналіз, метод польового моделювання структури концепту, метод суцільної вибірки, метод інтерпретації.

\section{Виклад основного матеріалу}

На сьогодні термін “концепт” задіяний у різних напрямах лінгвістики, у зв'язку із чим сформовано декілька підходів до тлумачення цього поняття, а саме: психологічний, логічний, філософський, культурологічний, лінгвокогнітивний, лінгвокультурологічний, інтегративний та багато інших. Виходячи із завдань цього дослідження визначення специфіки лексикалізації концепту СТАТУС у сучасному британському художньому дискурсі за допомогою культурно маркованої лексики, - за робоче визначення концепту приймаємо його трактування в межах лінгвокультурологічного підходу як «одиниці колективного знання / свідомості, що відсилає до вищих духовних 
цінностей, має мовне втілення і відзначене етнокультурною специфікою» (Воркачов, 2001: 70).

Опис концепту як ментальної одиниці передбачає з'ясування його змісту, утворюваного сукупністю дистинктивних когнітивних ознак (або його мікрокомпонентів), і опис його структури (макрокомпонентів) як необхідної умови буття концепту (Приходько, 2013).

Як складна структурована одиниця свідомості концепт має польову структуру, у якій виокремлюють поняттєвий, образний та ціннісний складники (макрокомпоненти) (Воркачов, 2004: 7). Перша становить ядерну зону концепту, друга й третя - його периферію. Поняттєвий компонент віддзеркалює ознакову й дефініційну структуру концепту та складається із сукупності дистинктивних ознак поняття, що утворює його номінальне визначення (Мартінюк, 2006: 101-107), яке збігається з предметною частиною лексичного значення слова імені концепту. Образний складник концепту заснований на когнітивних метафорах, що підтримують концепт у свідомості (Воркачов, 2005: 7). Лінгвокультурний концепт відрізняється акцентуацією ціннісного елементу, який визначається актуальністю (реалізується за допомогою чисельних мовних одиниць) та оцінністю (знаходить вираження в оцінному складнику значення мовної одиниці, що виступає ім'ям концепту, а також у поєднанні цієї одиниці з оцінною лексикою, епістемами) (Стернин, \& Розенфельд, 2008: 23).

У структурі концепту, услід за Й. А. Стерніним та М. Я. Розенфельдом (Стернин, \& Розенфельд, 2008), також виявляємо ознаки, що не входять до його дефініційного мінімуму. Вони є енциклопедичними, надлишковими й отримали назву акцидентальних (Bierwish, \& Kiefer, 1969). Такі ознаки знаходять віддзеркалення в енциклопедичному полі (макрокомпоненті) концепту та надають відомості про онтологічні характеристики явища, що концептуалізується, які засвоюють носії мови в процесі отримання життєвого досвіду й практичної взаємодії з предметом або явищем, що концептуалізується (Стернин, \& Розенфельд, 2008: 158). До енциклопедичних ознак концепту зараховують родову ознаку явища, що концептуалізується (категоріальна зона енциклопедичного поля концепту), ознаки, що відрізняють концепт від близьких до нього за змістом видових концептів (диференційна зона енциклопедичного поля концепту), багаточисленні ознаки, що характеризують різноманітні аспекти й прояви предмета 
або явища, відомості про які отримані носіями мови в процесі суспільного або індивідуального досвіду пізнання предмета або явища в різноманітних ситуаціях, когнітивні ознаки, що віддзеркалюють зв'язок концепту з побутом і культурою народу (традиціями, історією тощо /описова зона енциклопедичного поля концепту/) та сукупність ознак, що індивідуалізують концепт, тобто ілюструють типове матеріальне втілення концепту в реальній дійсності й несуть інформацію про конкретний прототип явища, що концептуалізується (ідентифікаційна зона енциклопедичного поля концепту) (Стернин, \& Розенфельд, 2008: 160-161).

Окрім енциклопедичного поля концепту, у його структурі можуть виявлятися особливості, що інтерпретують його дистинктивні ознаки та енциклопедичний зміст. Вони формують інтерпретаційне поле (макрокомпонент) концепту, у якому також виокремлюють зони. Зокрема, оцінна зона інтерпретаційного поля об'єднує когнітивні ознаки, що виражають загальну оцінку, а також оцінку за будьяким конкретним параметром (естетичним, моральним, емоційним тощо). Утилітарна зона об’єднує когнітивні ознаки, які виражають прагматичне ставлення носіїв мови до явища, що концептуалізується, і відбивають знання, пов'язані з можливістю та особливостями використання предмета або явища людьми для будь-яких практичних цілей - інформацію про те, для чого потрібен предмет, чого за його допомогою можна досягти, про умови його функціонування, які наслідки для людини несе його використання, яких дій потребує з боку людей цей предмет або явище тощо. Регулятивна зона об’єднує наказові когнітивні ознаки - такі, що вказують на те, чого не треба робити 3 предметом, що концептуалізується, або явищем, що покриває концепт (Стернин, \& Розенфельд, 2008: 162-163).

Зміст концепту віддзеркалює загальні когнітивні ознаки, виявлені в процесі аналізу предмета, що концептуалізується. Їх виокремлення стає можливим завдяки апеляції до засобів вербалізації концепту на рівні узусу (імені концепту, складників його синонімічного ряду) та на рівні дискурсу, що реалізується в природному побутуванні вербальних репрезентантів концепту (Приходько, 2013: 63-65).

Розв'язання проблеми реалізації / онтологізації концептів - виведення їх внутрішнього змісту (плану змісту) назовні, тобто їх екстеріоризація, - одне з головних завдань когнітивної лінгвістики 
(Приходько, 2013: 77). Концепт є дисперсним ментальним утворенням, що втілюється / реалізується низкою вербальних і навіть невербальних засобів (Приходько, 2013: 78).

За умови вербалізації концепту він отримує статус лексичного, у якому кодується схематичний мовний зміст [Evans, 2017], утілений у двох комплементарних підсистемах - граматичній та лексичній (Talmy, 2000). Репрезентація концепту лексичною підсистемою залучає відкритий клас форм (іменник, прикметник, прислівник, дієслово) й називається лексикалізацією, за якої надається доступ до детальної (мультимодальної) інформації, що співвідноситься із зовнішнього середовища та взаємодією людини з довкіллям, моторними аспектами функціонування людського тіла та емоційним досвідом людини (Evans, 2009).

У фокусі уваги цього дослідження - культурно марковані лексичні одиниці, що залучаються задля об'єктивації концепту СТАТУС (або, іншими словами, лексикалізація концепту) у сучасному британському художньому дискурсі. Тож з'ясуємо сутність поняття “маркованість” у лінгвістиці, надамо визначення поняттю “культурно маркована лексична одиниця” та опишемо класифікацію культурно маркованих лексичних одиниць.

У лінгвістиці маркованість - це загальносеміотичне поняття, що його використовують на позначення ознаки мовної одиниці, яка сигналізує про іiі дивергентість порівняно з базисною (немаркованою) формою - такою, що зберігається в процесі нейтралізації (Давыдова, \& Литвинчук, 2017). Маркованість, як правило, описують у термінах опозиції: маркований член - немаркований (базисний) член. Основними одиницями аналізу під кутом зору категорії маркованості є фонологічні, морфологічні, лексичні й синтаксичні феномени.

Культурно марковану лексику, що є об’єктом цього дослідження, визначаємо як сукупність лексичних одиниць, які є безпосередніми носіями інформації про специфічні риси культури певної мовної спільноти (Давыдова, \& Литвинчук, 2017). До культурно маркованої лексики зараховують: 1) реалії - слова, що позначають предмети і явища тільки однієї культури й народу та які не існують в іншій культурі (Влахов, \& Флорин, 1980: 16); 2) фонову лексику - слова, позначення яких $\epsilon$ в різних культурах, але їхній національний фон збігається не точно (частково марковані лексичні одиниці), наприклад, 
кулага - теss, вянок - net: а) денотативно марковані (такі, що відзначаються культурно маркованим денотатом) та б) конотативно-марковані (такі, що характеризуються культурно маркованим конотатом) (Караткевіч, 2008).

Як уже зазначалося, лексичні одиниці є одним з основних засобів об’єктивації концептів. Культурно маркована лексика, віддзеркалюючи національну специфіку народного сприйняття світу, охоплює величезний пласт мови, у якій одиниці культурно маркованої лексики вказують на національну своєрідність фонду мови, народу й культури. Цікавим є питання щодо того, які концептуальні ознаки об'єктивує національно-культурна семантика таких мовних одиниць, і те, яке місце ці ознаки посідають у структурі концепту. На це питання може дати відповідь емпіричний аналіз культурно маркованої лексики як способу об’єктивації в британському художньому дискурсі СТАТУСу - одного з пріоритетних концептів британської лінгвокультури через кастову структуру суспільства, що закріплена релігією і законом.

Передусім дослідимо реалії як основу лексикалізації концепту СТАТУС. Аналіз фрагментів британського художнього дискурсу, у яких функціонують лексичні одиниці, що об’єктивують концепт СТАТУС, дав змогу виявити такі реалії:

a) ойконіми (географічні реалії-топоніми, що є назвами населених пунктів): (1) He was inordinately proud of her and her career, it was a big leap for a girl from Clapham, from a secondary modern. Being an air hostess was about as good a career as a girl could hope for. As good as being a private secretary, only with more prestige. The uniforms, the foreign travel, the dashing pilots (Vincenzi, 2011). У дискурсивному фрагменті (1) функціонує ойконім Clapham - назва району в південно-західному Лондоні. Йому надають перевагу студенти, небагаті родини з дітьми, оскільки він знаходиться далеко від суєти центральної частини міста і є недорогим районом. Саме тому ця частина міста асоціюються з простим життям, без розкоші й надмірностей. Такій репутації також сприяє той факт, що у 18 столітті Клапем був передмістям для робітничого класу. У фрагменті (1) мова йде про просту дівчину, яка виросла у Клапемі - бідному районі Лондона - і змогла зробити гарну кар'єру. Проживання в Клапемі є ознакою низького статусу людини й надає факту того, що така людина змогла зробити гарну кар'єру, особливого значення. Отже, ойконім Clapham реалізує концепт СТАТУС 
шляхом указівки на те, що проживання в бідному районі міста свідчить про низький соціальний статус людини. Ця когнітивна ознака концепту СТАТУС (“проживання у бідному районі міста”) виокремлюється в описовій зоні енциклопедичного поля досліджуваного концепту, оскільки відбиває властивості та прояви концепту, отримані носіями мови в процесі набуття громадського й особистого досвіду, що в тих чи тих ситуаціях виявлялися істотними для людей;

б) освітні реаліі: (2) The other public school wellies, as he thought of them, were wellies indeed: "thick as the proverbial," he remarked to Nobby one night as they polished their boots. "I mean, Chas, he's got a brain in 'is 'ead, but these two 'aven't. I reckon we could get the better of 'em, you and I, Nobs, if only got half a chance (Vincenzi, 2011).” У фрагменті (2) функціонує освітня реалія public school на позначення приватної школи, яку відвідують діти привілейованих прошарків суспільства (у британському варіанті англійської мови приватна школа називається публічною, оскільки передбачається, що такий заклад освіти можуть відвідувати діти, чиї батьки $є$ представниками платоспроможної публіки - прим. M. Б.). Указівка на те, що людина відвідує або відвідувала таку школу, автоматично зараховує іï до верств суспільства, об'єктивуючи концепт СТАТУС, а саме його когнітивну ознаку “відвідування приватного закладу середньої освіти”, що є описовою ознакою енциклопедичного поля досліджуваного концепту.

Наведемо ще один приклад освітньої реаліі: (3) Ivor Lewis looked at Matt across his large desk; he was larger than life. Six foot two, sixteen stone of aggression; grammar school and red-brick university, expensive, and reputedly unbeatable in the divorce courts (Vincenzi, 2011). Grammar school школа в Британії для дітей, старших 11 років, які мають скласти спеціальний іспит, щоб навчатися в ній. Grammar schools зосереджені на поглибленому вивченні гуманітарних предметів з припущенням, що багато їхніх учнів продовжать навчання у ВНЗ, тому, якщо особу схарактеризовано із залученням інформації, що вона відвідувала grammar school, це свідчить про іï високі інтелектуальні здібності, а отже, і високий статус. Отже, освітня реалія grammar school лексикалізує когнітивну ознаку “відвідування закладу середньої освіти із поглибленим вивченням предмета” описової зони енциклопедичного поля концепту. 
Red-brick universities - неформальний термін, що позначає групу із шести престижних університетів Англії, розташованих у великих промислових містах. Усі ці ВНЗ були спочатку засновані як коледжі прикладних або інженерних дисциплін, однак отримали статус університетів до початку Першої світової війни. Після 1992 року термін перетворився зі зневажливого на символ респектабельності. Отже, освітня реалія red-brick university лексикалізує когнітивну ознаку “відвідування престижного університету” описової зони енциклопедичного поля концепту, адже, якщо людина навчалася в такому університеті, це свідчить про ії високий соціальний статус;

в) соціальні реалії, що є назвами громадських організацій та установ: (4) He had a very big job at $\underline{K D P}$, he was a Group Account Director, a breed known at the agency as the Lords. "And a few of them actually are", Jeremy said, grinning at her. "Lords, I mean" [Vincenzi, 2011]. У фрагменті (4) спостерігаємо реалію, що називає установу в Лондоні - KDP. Це велика інвестиційна компанія, яка займається аналізом ринку, клієнти якої - видатні бізнесмени. Факт роботи людини в такій компанії $€$ прямою вказівкою на її високий соціальний статус, оскільки з цього випливає, що така вона має гарну освіту й взаємодіє з клієнтами, які належать до бізнес еліти. Подібні асоціації з фактом роботи людини в KDP $є$ когнітивною ознакою концепту СТАТУС “робота в престижній організації, яка $є$ описовою ознакою енциклопедичного поля досліджуваного концепту: те, що престижна робота $є$ віддзеркаленням високого соціального статусу, є стереотипним уявленням британців.

У наведеному фрагменті (4) також функціонує г) соціальна реалія Lord, що є офіційним спадковим титулом у Великобританії, а також назвою особи, що носить цей титул. Історично титул лорда носять переважно представники вищої британської аристократії, а приналежність до аристократії свідчить у країні про високий соціальний статус особи. Отже, реалія об’єктивує когнітивну ознаку “приналежність до аристократії, що є описовою ознакою енциклопедичного поля концепту СТАТУС, оскільки традиційно лорди протиставлялися простолюду.

Розглянемо приклади об'єктивації концепту денотативно-маркованою лексикою.

(5) "The Eliza one. She's getting engaged. And I'm afraid I was right. To someone pretty blue-blooded (Vincenzi, 2011)”. У фрагменті (5) 
спостерігаємо лексему blue-blooded, яка визначається в словнику (CD) як 'a person belonging to a family that has a high social rank'. Указівка на приналежність людини голубої крові до соціальної верхівки наявна в денотативному значенні лексеми, що аналізується (слова-ідентифікатори belonging to a high social $\underline{\text { rank}})$, яке передає загальне логічне поняття, укладене в слові. Це свідчить про те, що когнітивна ознака “наявність голубої крові” - частина поняттєвого компоненту концепту СТАТУС.

(6) "I think it's because you are posh", Fiona said. "Takes a nob to know one". "I am not a nob", said Eliza crossly". She spent a lot of time trying to shed this image, in what was supposed to be the new classes society; nothing seemed to work (Vincenzi, 2011). Наведений фрагмент (6) сигналізує про функціонування денотативно маркованих лексем, що об’єктивують концепт СТАТУC, - posh та nob. Лексему posh (LDCE, 1989) визначає як 'upper class', а лексему nоb - як 'a rich person with a high social position', денотативні значення яких містять пряму вказівку на приналежність суб'єктів до високого соціального класу (слова-ідентифікатори upper class, rich, high social position), об’єктивуючи в такий спосіб поняттєву ознаку концепту СТАТУС “приналежність до вищої касти суспільства".

(7) He'd never recognized him, Matt, thought, he looked exactly like all the other toffs round here, rolled umbrella, bowler hat, pinstripe suit (Vincenzi, 2011). У фрагменті (7) функціонує лексема toff, денотативне значення якої сигналізує про об’єктивацію когнітивної ознаки, що входить до поняттєвого ядра концепту СТАТУС - "a rich person with a high social position" (LDCE, 1989), отже, лексему зараховуємо до одиниць денотативно маркованої фонової лексики як способу мовного подання концепту СТАТУС.

Розглянемо випадки об'єктивації концепту конотативно-маркованою лексикою.

(8) I've got the most amazing and brilliant job. I'm so excited. It's everything I hoped for, in fashion, not just secretarial - oh, Mummy, I'm so happy (Vincenzi, 2011). У наведеному фрагменті (8) героїня розповідає матері про успіхи в кар'єрі, які, безумовно, свідчать про підвищення iii соціального статусу. При цьому вона уточнює, що знайшла роботу у сфері моди. Денотативне значення слова fashion - 'something that is popular or thought to be good at a particular time’ не свідчить про те, 
що воно є засобом об’єктивації концепту СТАТУС. Але моду можна розглянути як проєкцію уявлень про престиж, що є сукупним критерієм соціального статусу: для успішних людей важливим є стиль в одязі й слідування моді. Крім того, видатні дизайнери у сфері моди $є$ також успішними бізнесменами. Тож зв'язок моди й успіху як індикатора статусу можна зарахувати до утилітарної зони інтерпретаційного поля концепту СТАТУС, що сигналізує про прагматичне ставлення носіїв мови до моди та можливостей ії використання для досягнення певних цілей (модний одяг сигналізує про досягнення успіху, а отже, про високий соціальний статус).

Крім того, до лексем, що залучаються в дискурсі до об’єктивації концепту СТАТУС, можна віднести такі, що називають певні предмети одягу, які є стильними та консервативними, та аксесуари, наприклад, bowler hat, pinstripe suit, rolled umbrella. Зокрема, парасолька-тростина $є$ довгою, тому іiі незручно носити в руці, однак нею, як правило, користуються успішні люди, які пересуваються лише автомобілем і використовують ії лише для того, щоб дійти від авто до будівлі. Тому назви зазначених предметів можна також вважати способами об'єктивації концепту СТАТУС: ((9) He'd never recognized him, Matt, though, he looked exactly like all the other toffs round here, rolled umbrella, bowler hat, pinstripe suit (Vincenzi, 2011).

(9) "My darling Scarlett, the American is every bit as snobby as the Englishman, possibly more, always stressing how far back his family goes, denying anything remotely nouveau, fighting to get into the right schools and colleges, launching debutantes into society - it's all just the same. You have to be Old Money, with capital letters, or you might as well not have any at all" (Vincenzi, 2011). У дискурсивному фрагменті (9) функціонують дві конотативно-обтяжені лексичні одиниці: 1) поиvеаи зі значенням 'having only recently become rich and spending a lot of money' (CD, 1991) та 2) Old Money зі значенням 'used to refer to rich people whose families have been rich for a long time» (CD, 1991). Обидві лексичні одиниці мають у словнику позначку 'used to show disapproval'. Їх використовують на позначення багатої людини, але вони віддзеркалюють ідею про те, що наявність грошей не гарантує високого статусу в суспільстві. Зокрема, якщо статок багатої людини - це “старі гроші" (успадковане багатство), це означає, що він належить багатим людям, які змогли зберегти своє багатство протягом кількох поколінь 
і належать до аристократії, тобто вищого класу. “Старі гроші” завжди вважилася представниками вищого класу, на відміну від нуворишів, навіть якщо останні мали більше багатства. Подібні уявлення $\epsilon$ прагматичним ставлення до успадкованого й надбаного багатства, віддзеркалюють когнітивну ознаку “спосіб збагачення”, яку ми зараховуємо до утилітарної зони інтерпретаційного поля концепту СТАТУС.

До конотативно маркованої фонової лексики, що об’єктивує концепт СТАТУС, також зараховуємо лексичні одиниці, які вказують на расову приналежність. Расизм дає про себе знати в різних сферах життя людства: у повсякденних уявленнях, сфері політики й навіть науці. Традиційно під расизмом розуміють концепцію, що, по-перше, зводить усі відмінності між людьми (у культурі, поведінці, світосприйнятті) до расових ознак, які нібито виявляються в таких фізичних ознаках, як колір шкіри, форма носа, розріз очей, форма й колір волосся та ін., а по-друге, проголошує на цій підставі довічну нерівність рас. Споконвічно вищою расою вважалася біла, передусім через колоніальну історію європейців. Чорна раса традиційно була нижчою через той факт, що чорними були раби. Наприклад, у наступному фрагменті опис суб’єкта як представника білої раси надає йому високого соціального статусу, що підкріплено атрибутом big: (10) "I am told by the big white chief you could help us. He says I should talk to you. Over lunch perhaps" (Vincenzi, 2011). Оскільки описані уявлення про представників білої раси $є$ прагматичним ставленням носіїв мови, цю ознаку “приналежність до певної раси” зараховуємо до утилітарної зони інтерпретаційного поля досліджуваного концепту.

\section{Висновки}

Звернення до аналізу фрагментів сучасного британського художнього дискурсу дало змогу зробити висновок, що для лексикалізації концепту СТАТУС виявляються затребуваними:

1) реалії, а саме ойконіми (Clapham, Islington, Chelsea); освітні реалії (secondary modern, public school, Upper Sixth, grammar school, redbrick university); соціальні реалії, що називають громадські організації та установи (KPD); соціальні реалії на позначення спадкових титулів (lord, count).

Зазначені реалії репрезентують такі когнітивні ознаки, як “проживання в бідному / престижному районі міста”, “відвідування безоплатного державного / приватного закладу середньої освіти”, “відвідування 
закладу освіти з поглибленим вивченням предмета”, “націленість на отримання вищої освіти”, “навчання в престижному університеті”, “робота в престижній організації”, “приналежність до аристократії, які належать до описової зони енциклопедичного поля концепту СТАТУС і відбивають ті властивості / прояви концепту, що отримані носіями мови в процесі набуття громадського й особистого досвіду, віддзеркалюючи національний спосіб сприйняття дійсності, що визначається сукупністю когнітивних стереотипів британської нації;

2) денотативно маркована фонова лексика, до складу якої входять лексеми, що у своїх дефініціях мають безпосередню вказівку на статус завдяки певним словам-ідентифікаторам (blue-blooded, nob, posh, toff, born with the silver spoon in the mouth, CEO, great, slummy). Ці одиниці реалізують когнітивні ознаки "наявність голубої крові”, “приналежність до вищої касти суспільства”, “наявність в особи успіху й слави”, “погано вдягнена людина з непривабливою зовнішністю”, які входять до понятійного ядра концепту СТАТУС;

3) конотативно маркована фонова лексика, у якій статус реалізується в конотативному значенні (in fashion, a sports car manufacturer, bowler hat, pinstripe suit, rolled umbrella, black tie, silk dress, high heels, palazzo pajamas, smoking jacket, do cleaning job, building job, nouveau, Old Money). Виявлені лексичні одиниці слугують для вказівки на статусну роль суб'єкта через такі додаткові ознаки, як: а) факт зайнятості в таких професійних сферах, як мода або виробництво спортивних авто, що є проєкцією уявлень про престиж або факт приналежності до професії, за узагальненим образом якої закріпився стереотип «непрестижно»; б) носіння суб’єктами з високою статусною роллю певних предметів одягу й аксесуарів, які є уособленням стилю та консервативності; в) спосіб збагачення, адже наявність високого статусу в британському суспільстві може гарантувати лише успадковане майно, яким володіли покоління; г) факти приналежності певній расі, адже довічна нерівність білої та чорної рас, що сягає корінням у колоніальну історію європейців, у т.ч. й британців, додає престижу білій расі та зневажливого ставлення - чорній.

Перспективу дослідження вбачаємо у встановленні когнітивних ознак інших концептів, що лексикалізуються за допомогою культурно маркованих одиниць у сучасному британському художньому дискурсі. 


\section{ЛІТЕРАТУРА}

1. Влахов, С., \& Флорин, С. (1980). Непереводимое в переводе. Москва: Междунар. отношения. 2. Воркачев, С.Г. (2001). Лингвокультурология, языковая личность, концепт: становление антропоцентрической парадигмы в языкознании. Филологические науки, 1, 64-72. 3. Воркачов, С. Г. (2004). Счастье как лингвокультурный концепт. Москва: Гнозис. 4. Давиденко, О. А. (2019). Культурний простір як основа формування концептів. Закарпатські філологічні студіi, 9, 84-87. 5. Давыдова, С. А., \& Литвинчук, А. И. (2017). Культурно-маркированная лексика как отражение национальной самобытности культуры. Международный научный журнал, Филология, 5 (11), 236-242. 6. Домніч, О. В. (2017). До питання про поняття лінгвокультурний концепт та методику його дослідження. Мовні і культурні картини світу, 6, 71-80. 7. Єфимчук, Г. О. (2018). Лінгвальні та соціолінгвальні особливості вербалізації концепту ARROGANCE у британські картині світу. (Автореф. дис. ... канд. філол. наук). Запоріжжя: ЗНУ. 8. Караткевіч, У. С. (2008). Дзікае паляванне караля Стаха: аповесцью. Мінск: Беларусь. 9. Мартинюк, А. П. (2006). Регулятивна функція гендерно маркованих одиниць мови (на матеріалі сучасного англомовного публіцистичного дискурсу). (Автореф. дис. ... докт. філол. наук). Київ: Київ. нац. ун-т імені Т. Шевченка. 10. Приходько, А. Н. (2013). Кониепты и кониептосистемы. Днепропетровск: Белая Е. А. 11. Саєвич І.Г. (2013). Ключові концепти культури: критерії виокремлення. Слово і речення: синтактика, семантика, прагматика. Матеріали Міжнар. наук. конф. (10-20 жовтня 2013 р.) (с. 249-255). Київ: Київ. ун-т імені Бориса Грінченка. 12. Сергієнко, В. Л. (2015). Лінгвокультурні концепти PRIDE і NOBILITY у британській мовній картині світу. (Дис. ... докт. філол. наук). Чернівці: Чернів. нац. ун-т імені Юрія Федьковича. 13. Стернин, И. А., \& Розенфельд, М. Я. (2008). Слово и образ. Воронеж: Истоки. 14. Чумакова, К. А. (2017). Лінгвокультурні параметри вербалізації концепту TRANSPORT у британському та американському варіантах англійської мови. (Дис. ... канд. філол. наук). Запоріжжя: ЗНУ. 15. Bierwish, V., \& Kiefer, F. (1969). Remarks on Definition in Natural Language. Studies in Syntax and Semantics, 10, 55-79. 16. CD (1991) - Cambridge Dictionary. Узято з https://dictionary.cambridge.org. 17. Evans, V. (2009). How Words Mean: Lexical Concepts, Cognitive Models and Meaning Construction. Oxford: Oxford University Press. 18. Evans, V. (2010) On the Nature of Lexical Concepts. Узято з http:www.semanticscholar.org. 19. LDCE (1989) - Longman Dictionary of Contemporary English. Узято 3 https://www.ldoceonline.com. 20. Talmy, L. (2000) Toward a Cognitive Semantics: Concept Structuring Systems. (Vol. 1). Cambridge, MA: MIT Press. 21. Talmy, L. (2000). Toward a Cognitive Semantics: Typology and Process in Concept Structuring. (Vol. 2). Cambridge, MA: MIT Press. 22. Vincenzi, P. (2011). The Decision. London: Headline Publishing Group.

\section{REFERENCES}

1. Vlahov, S., \& Florin, S. (1980). Neperevodimoe v perevode [Untranslated in translation]. Moskva: Mezhdunar. otnosheniya [in Russian]. 2. Vorkachev, S. G. (2001). Lingvokulturologiya, yazyikovaya lichnost, kontsept: stanovlenie antropotsentricheskoy paradigmyi v yazyikoznanii [Linguoculturology, language personality, concept: the formation of anthropocentric paradigm in linguistics]. Filologicheskie nauki - Philological sciences, 1, 64-72 [in 
Russian]. 3. Vorkachov, S. G. (2004) Schaste kak lingvokulturnyiy kontsept [Happiness as a linguocultural concept]. Moskva: Gnozis [in Russian]. 4. Davidenko, O. A. (2019). Kulturniy prostir yak osnova formuvannya kontseptiv [Cultural space as a grounding of concept formation]. Zakarpatski filologichni studiyi - Transkarpathian philological studies, 9, 84-87 [in Ukrainian]. 5. Davyidova, S. A., \& Litvinchuk, A. I. (2017). Kulturno-markirovannaya leksika kak otrazhenie natsionalnoy samobyitnosti kulturyi [Culturally-marked lexis as a reflection of national uniqueness of culture]. Mezhdunarodnyiy nauchnyiy zhurnal, Filologiya - International scientific journal, Philology, 5 (11), 236-242 [in Russian]. 6. Domnich, O. V. (2017). Do pitannya pro ponyattya lingvokulturniy kontsept ta metodiku yogo doslidzhennya [Towards the issue of the notion of linguo-cultural concept and the methodology of its investigation]. Movni i kulturni kartini svitu - Linguistic and cultural pictures of the world, 6, 71-80 [in Ukrainian]. 7. Efimchuk, G. O. (2018). Lingvalni ta sotsiolingvalni osoblivosti verbalizatsiyi kontseptu ARROGANCE u britanski kartini svitu [Lingual amd socio-lingual peculiarities of the verbalization of the concept ARROGANCE in the British world view]. Extended abstract of candidate's thesis. Zaporizhzhia: ZNU [in Ukrainian]. 8. Karatkevich, U. S. (2008). Dzikae palyavanne karalya Staha: apovestsyu [King Stakh's wild hunt: a narrative]. Minsk: Belarus [in Belarussian]. 9. Martinyuk, A. P. (2006). Regulyativna funktsiya genderno markovanih odinits movi (na materiali suchasnogo anglomovnogo publitsistichnogo diskursu) [Rugulative function of gender marked linguistic units (on the material of the present-day English language publicist discourse)]. Extended abstract of doctor's thesis. Kyiv: Kyiv. nats. un-t imeni T. Shevchenka [in Ukrainian]. 10. Prihodko, A. N. (2013). Kontsepty $i$ kontseptosistemy [Concepts and conceptual systems]. Dnepropetrovsk: Belaya E. A. [in Ukrainian]. 11. Saevich, I. G. (2013). Klyuchovi kontsepti kulturi: kriteriyi viokremlennya [Key concepts of culture: kriteriyi viokremlennya]. Slovo i rechennya: sintaktika, semantika, pragmatika. Materialy Mizhnar. nauk. konf. - International scientific conference "A word and a sentence: synthetics, semantics, pragmatics». Kyiv: Kyiv. un-t imeni Borysa Hrinchenka [in Ukrainian]. 12. Sergienko, V. L. (2015). Lingvokulturni kontsepti PRIDE I NOBILITY u britanskiy movniy kartini svitu [Linguo-cultural concepts PRIDE I NOBILITY] in the British linguistic world view]. Candidate's thesis. Chernivtsi: Cherniv. nats. un-t imeni Yuriia Fedkovycha [in Ukrainian]. 13. Sternin, I. A., \& Rozenfeld, M. Ya. (2008). Slovo i obraz [Word and image]. Voronezh: Istoki [in Russian]. 14. Chumakova, K. A. (2017). Lingvokulturni parametri verbalizatsiyi kontseptu TRANSPORT u britanskomu ta amerikanskomu variantah angliyskoyi movi. Candidate's thesis. Zaporizhzhia: ZNU [in Ukrainian]. 15. Bierwish, V., Kiefer, F. (1969). Remarks on Definition in Natural Language. Studies in Syntax and Semantics, 10, 55-79 [in English]. 16. CD (1991). - Cambridge Dictionary. Retrieved from https://dictionary.cambridge.org [in English]. 17. Evans, V. (2009). How Words Mean: Lexical Concepts, Cognitive Models and Meaning Construction. Oxford: Oxford University Press [in English]. 18. Evans, V. (2009). On the Nature of Lexical Concepts. Retrieved from: http:www.semanticscholar.org [in English]. 19. LDCE (1989). - Longman Dictionary of Contemporary English. Retrieved from https://www.ldoceonline.com [in English]. 20. Talmy, L. (2000) Toward a Cognitive Semantics: Concept Structuring Systems. (Vol. 1). Cambridge, MA: MIT Press [in English]. 21. Talmy, L. (2000). Toward a Cognitive Semantics: Typology and Process in Concept Structuring. (Vol. 2). Cambridge, MA: MIT Press, 2000. 22. Vincenzi, P. (2011). The Decision. London: Headline Publishing Group [in English]. 
Бєлова Марина Олександрівна - кандидат філологічних наук, доцент, доцент кафедри англійської філології, Харківський національний педагогічний університет імені Г. С. Сковороди; вул. Валентинівська, 2, м. Харків, 61168, Україна.

Tel.: +38050-631-87-40

E-mail: marynavasylieva2005@gmail.com

http://orcid.org/000-0002-1306-9305

Bielova Maryna Oleksandrivna - Candidate of Philological Sciences (Ph.D.), Docent, Associate Professor at the Department of English Philology, H. S Skovoroda Kharkiv National Pedagogical University; 2 Valentynivska Str., Kharkiv, 61168, Ukraine.

Надійшла до редакції 10 березня 2021 року

\section{CITATION}

ДСТУ 8302:2015: Бєлова М. О. Культурно маркована лексика як засіб об’єктивації концепту СТАТУС (на матеріалі британського художнього дискурсу). Лінгвістичні дослідження: зб. наук. пр. Харк. нац. пед. ун-ту імені Г. С. Сковороди. Харків, 2021. Вип. 54. Ч. I. С. 197-212. DOI: https://doi.org/10.34142/23127546.2021.54.1.17

APA: Бєлова, М. О. (2021). Культурно маркована лексика як засіб об’єктивації концепту СТАТУС (на матеріалі британського художнього дискурсу). Лінгвістичні дослідження, 54 (I), 197-212. DOI: https://doi.org/10.34142/23127546.2021.54.1.17 